\title{
Analysis the Status of Land Readjustment (LR) in Urban Development of Iranian Cities, A Case of Gonabad Neighborhood Garden
}

\author{
Dr. Mohammad Rahim Rahnama1 \\ Marjan Akbari ${ }^{\star}$ \\ ${ }^{1}$ Associated Professor of Geography and Urban Planning, Ferdowsi University of Mashhad, Iran \\ $2^{*}$ Ph.D. student of Geography and Urban Planning, Ferdowsi University of Mashhad \\ International Campus, Iran (corresponding author, M-akbari-s@hotmail.com
}

Doi:10.5901/mjss.2016.v7n2s1p301

\begin{abstract}
Land Readjustment is a practical model in management of land development in the urban development process and maybe it can be said that the land readjustment has been used by different countries in last decades. In order to, the purpose of this research is analysis the status of land readjustment $(L R)$ in urban development of Iranian cities with point on Gonabad neighborhood garden. Applied methodology is descriptive - analytical, based on library studies, modeling, and field survey studies. In continuous, we have used of LR patterns. Results showed that the total nominal value of the units before the program was 23.761 .115 and after the run of program, it was equal to $32,710,627$ units. Finally, it has been presented some solution's in the end of paper.
\end{abstract}

Keywords: LR, Urban Management, Urban Projects, Gonabad Neighborhood, Mashhad city

\section{Introduction}

Land Readjustment (LR) is one of the effective land acquisition methods. This method is used for developing and improving urban infrastructure. It also enhances utility and value of land, so Land Readjustment is not a land acquisition method, but a kind of land consolidation method. Implementation of a Land Readjustment project, in certain areas, is accomplished by installing urban infrastructure by means of the land contribution of public facilities, according to a layout plan. On the other hand, it helps in financing project costs by allocating some central rearranged parcels for commercial land uses. In this method, rearrangement of all parcels has been made according to a new layout and land use plan and therefore, all land rights are legally transferred to the new parcels (Zakerhaghighi \& et al, 2013). In other wisp, Land Readjustment (LR) is a land development technique used in many countries around the world including Germany, Sweden, Japan, Taiwan and Korea. In essence it is a method whereby an irregular pattern of agricultural land holdings is re-arranged into regular building plots and equipped with basic urban infrastructure such as roads and drains (Sorensen, 2000; geometry.net). Land readjustment is implemented through "repotting". The conceptual framework of a LR project is shown below, involving a number of unique concepts such as "repotting", "contribution", etc. Since landowners and leaseholders equitably contribute a portion of their land in a LR project, a replot (building lot after LR) becomes smaller than the lot before LR. However, urban infrastructure developed under the LR project increases land values with an enhancement of efficient/effective utilization of building lots (Indian department of Personnel and Training, 2009, https://www.itc.nl/ ). There is no agreement among planners and professionals about the contribution of community participation in improving the lifestyle of people, especially the poor and disadvantaged people (www.asksource.info). Some completely dismiss its value altogether, while others believe that it is the 'magic bullet', that will ensure improvements especially in the context of poverty alleviation. Despite this lack of agreement, community participation has continued to be promoted as a key to development. Although advocacy for participation waxes and wanes, today, it is once again seen by many governments, the United Nations agencies and nongovernmental organizations (NGOs), as critical to program planning and poverty alleviation (World Bank, 1996, www.kubatana.net). In order to, the aim of this research is Analysis the Status of Land Readjustment (LR) in Urban Development of Iranian Cities with point on Gonabad Neighborhood Garden. 


\section{Background}

LR is a technique used for both the development of new areas and the reorganization of the structured areas in urban regions. Conditions for this efficient application of the LR Method can be considered under seven headings including, cost recovery, sharing of the project benefits and costs, including of infrastructure constructions and costs of LR process, conditions arising in terms of planning and public participation, number of technical personnel and management and quality of cadastral maps (Turk, 2007; Larsson, 1997).

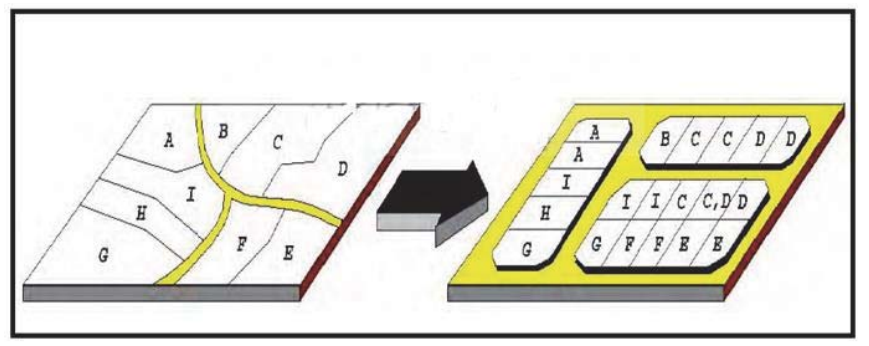

Figure 1. Plots of land reform and improving public facilities, the positive aspects of the reorganization plan.

Resource: Habibi \& Haji bandeh, 2009.

According to the article of 166 of the third program of socio-economic and cultural law of Iran Islamic Republic approved in 2000 based on allocation of the credit for the historical fabric the historical and cultural organization of the Esfahan Joibareh was begun in 2003 (Zabihi \& et al, 2012).

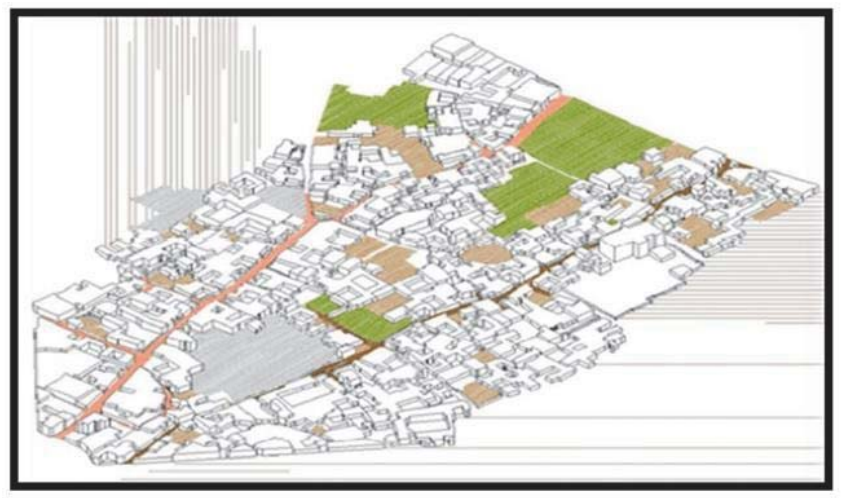

Figure 2. An example of historical and cultural organization in Isfahan.

Resource: Zabihi \& et al, 2012.

More than 100 years ago Franz Adickes, the previous Lord Mayor of Frankfurt am Main, created a law to force landowners to participate in so called land readjustment projects. The basic idea of this instrument is to exchange the plots of the landowners and not to expropriate them. The municipalities get the areas needed for public use, that can be extracted from the whole project area as a kind of land decrease ((JÖKEL. 2004; www.fig.net). 


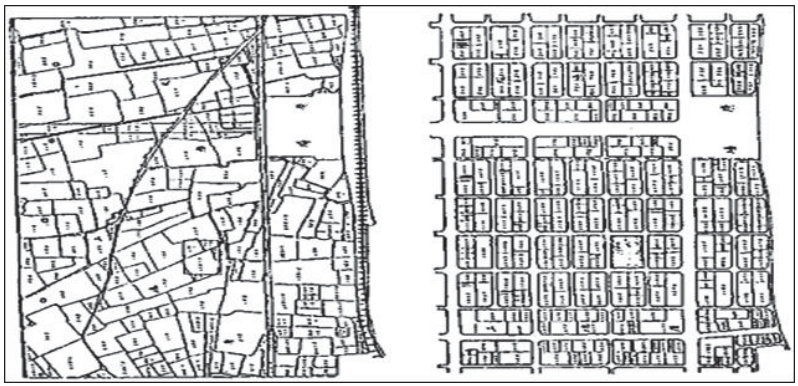

Figure 3. The first project of LR in Taiwan.

Resource: http://web.mit.edu/urbanupgrading/ upgrading/issues-tools/index.html The World Bank Group.

\section{Methodology}

Applied methodology is descriptive - analytical, based on library studies, modeling, and field survey studies. In continuous, we have used of LR patterns to evaluation the changes in case study region according to figure (4).

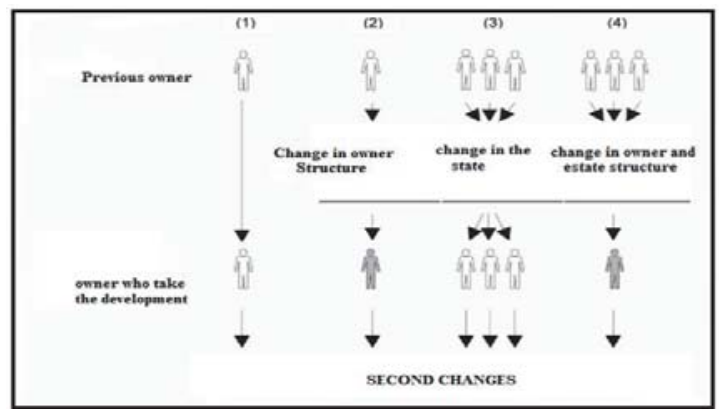

Figure 4. Previous and taken development in LR Gonabad Neighborhood Garden.

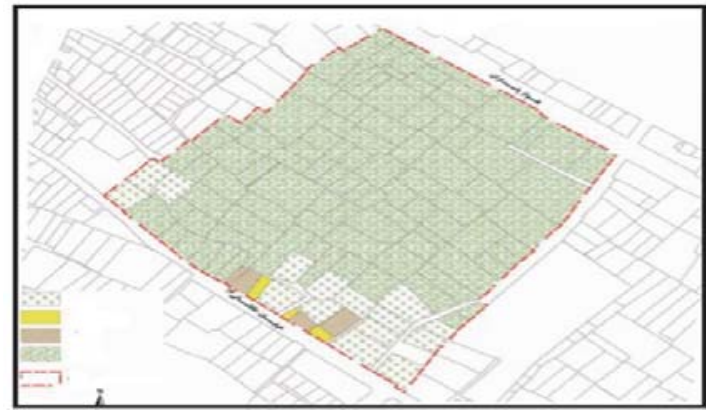

Figure 5. A view of Case study regions and its land uses.

\section{Findings and Results}

In other words, the process of land reform can be introduced as a way to develop the land on which the change in the pattern of land ownership, land distribution pattern has changed owners. For the implementation of land reform program, there are several stages in different countries, it is different according to the rules and policies related to land. In the 
meantime, perform calculations and redistribution of land are the main steps that can be seen in all the samples studied. The purpose of perform calculations of the land readjustment program is the estimated benefits and costs of development and determine the ownership participation in providing of these costs.

Table (1). Land use levels in the current status of case study region.

\begin{tabular}{|l|l|l|}
\hline Land Use & Area $\left(\mathrm{m}^{2}\right)$ & Proportion \\
\hline Residential & & \\
\hline Garden & & \\
\hline Agriculture & & \\
\hline Arid & & \\
\hline Total Land use & & \\
\hline Street network & & \\
\hline Total & & \\
\hline
\end{tabular}

To evaluate the feasibility parameter, in the beginning must be audited the real properties which are located in the study area. In order to, the characteristic of all parts of the area were recorded on the basis of field area, the lords area, land use and the type of owner. After the audit of real estates, The first block project was used in the framework of the regulations and detailed design criteria. Moreover, in the general orientation was considered adaptation the project with the climatic characteristics.

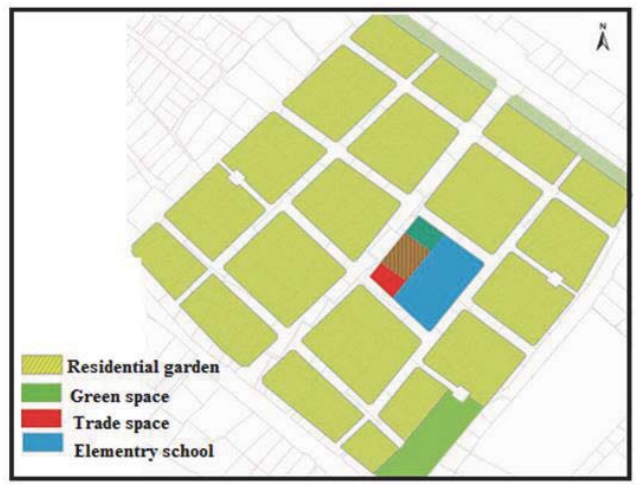

Figure 6. Block proposed based on studies in the case study region.

Based on the findings in table (2) about $60 \%$ of the ground level of must be allocated to residential garden. Also, respectively $5 / 7 \%$ to the services, $7 / 2 \%$ to green space and $30 \%$ remaining was dedicated to street network. The assigned block to the collection and dissemination the services adjacent streets and it is located in the near of complex center. In the next step would be to develop a range of costs arising from the study estimated. To make these estimates, we have prepared a list of these costs. These costs include the costs of four main categories consist of: design and development management, administrative cost of land preparation and construction of road networks, infrastructure construction cost and construction cost projected service spaces.

Table (2). Suggest Land use levels to case study region.

\begin{tabular}{|l|l|l|}
\hline Land Use & Area $\left(\mathrm{m}^{2}\right)$ & Proportion \\
\hline Residential & & \\
\hline Garden & & \\
\hline Agriculture & & \\
\hline Arid & & \\
\hline Total Land use & & \\
\hline Street network & & \\
\hline
\end{tabular}


Thus, by determine the weight of each criterion and enter the criteria in the equations, Results showed that the total nominal value of the units before the program was 23.761 .115 and after the run of program, it was equal to $32,710,627$ units. According to this, index feasibility in the case study region was obtained $a=1.38 \%$. Average value per square meter of land, before and after the program, 89/202 and 76/455 respectively estimated unit. At present, the trading price of land in the study area, per each meter was 1,000,000 Rials. Hence, according to the area of land transaction, before and after the program, the total value range respectively was 117.112 and 161.231 million Rials.

\section{Conclusion and Suggestions}

LR is a method whereby a group of land-owners can join forces to develop or redevelop land. In essence, it is a process whereby land-owners pool ownership of scattered and irregular plots of agricultural land, build roads and main infrastructure, and then sub-divide the land into urban plots (Sorensen, 2000). In the beginning must be audited the real properties which are located in the study area. In order to, the characteristic of all parts of the area were recorded on the basis of field area, the lords area, land use and the type of owner. After the audit of real estates. Average value per square meter of land, before and after the program, 89/202 and 76/455 respectively estimated unit. At present, the trading price of land in the study area, per each meter was 1,000,000 Rials. Hence, according to the area of land transaction, before and after the program, the total value range respectively was 117.112 and 161.231 million Rials. In order to, we can offer some suggestions as below:

1. Land supply must be according to citizen's demands rather financial benefits;

2. Making comprehensive and longtime plans about LR;

3. Give more role to citizens and urban managers about preparing LR plans and projects.

\section{References}

Habibi, M. Haji bandeh, M. (2009). Analysis the experience of using LR in Iran in compare with Japan. Hoviat Shahr Journal.

http://web.mit.edu/urbanupgrading/upgrading/issues-tools/index.html [3 May 2008]

http://web.mit.edu/urbanupgrading/upgrading/resources/glossary.html [3 May 2008]

Jökel. R. (2004). Land Readjustment - A Win-Win-Strategy for Sustainable Urban Development. TS14 Spatial Planning for Sustainable Development - Policies and Tools.

Larsson G (1997) Land readjustment a tool for urban development. Habitat Int. 21, 141-152.

Larsson, G., (1997). Land readjustment a tool for urban development, Habitat International., 21: 52-141.

Marcotullio. P. K (2003). "Globalization, Urban Form and Environmental Conditions in Asia-Pacific Cities", Urban Studies.

Sorensen A (2000) Conflict, consensus or consent: Implications of Japanese land readjustment practice for developing countries. Habitat Int. 24, 51-73.

Sorensen, A.. (2000). "Land readjustment and metropolitan growth: an examination of suburban land development and urban sprawl in the Tokyo metropolitan area", Progress in Planning.

The World Bank Group, (1996), issues-tools. Available from:

The World Bank Group, (2008). glossary. Available from:

Turk SS (2007) "An Examination for Efficient Applicability of the Land Readjustment Method at the International Context", Journal of Planning Literature.

World Land Readjustment development and Institutional growth of Japan Land Readjustment development. (2003). Urban development project.

www.asksource.info (2015).

www.fig.net (2015).

www.geometry.net (2015).

Zabihi, H \& ET AL, (2012). Analysis of land readjustment (LR) methods used in Joibareh, Iran. Indian Journal of Science and Technology Vol. 5 No. 2.

Zakerhaghighi, K.R taghadosl, M mahdavi. (2013). Planning and management for undeveloped lands in urban areas using land readjustment (case study: varamin city). Hoviateshahr fall 2013, volume 7 , number 15; page(s) 59 to 70. 